\title{
Selling Sensation, Creating Sanctity
}

\author{
The Visual and Material Culture of "Stigmatics"
}

\author{
Tine Van Osselaer
}

The core of the decision on whether or not the plaintiff's complaint is grounded, can be found in the answer to the question of whether or not the plaintiff can be counted among those people who have triggered a general interest of cultural importance in the public sphere, and as the events of recent years are well-known to the broadest public this question can be answered affirmatively. ${ }^{1}$

In November 1932, there seemed to be no doubt about the public status of Therese Neumann at a court case concerning a series of photographs taken of her. The German stigmatic had no right to hinder their circulation and had to forfeit every right to the use of her image:

The plaintiff herself seems to be aware that she belongs to the personalities of contemporary history, since she indicates in her complaint that half the civilized world knows about the unexplainable events. In the daily press and in the literature of recent years, the case of Therese Neumann plays a big role. Some books that only address "Konnersreuth" have already been published. ${ }^{2}$

1 "Der Kernpunkt der Entscheidung darüber, ob der von der Klägerin geltend gemachte Anspruch begründet ist, ist in der Beantwortung der Frage zu finden, ob die Klägerin zu den Personen zu zählen ist, die im öffentlichen Leben aus kulturellen (Interessen) Belangen ein allgemeines Interesse wachgerufen haben, diese Frage ist aber nach den in der breitesten Öffentlichkeit bekannten Vorgängen der letzten Jahre unbedingt zu bejahen." StA, Amtsgericht I Waldsassen 441: Therese Neumann, Konnersreuth, gegen A.H., wegen Verletzung am Bilde 1932-1935 (Neumann/A.H.). Der Oberamtsrichter: Neumayer, Verkündet am 15. November 1932.

2 "Die Klägerin selbst scheint (dieses) zu fühlen, dass sie zu den Personen der Zeitgeschichte zählt, weil sie in der Klageschrift anführen lässt, dass der halben zivilisierten Welt die ungeklärten Vorgänge bekannt sind. In der Tagespresse und in der Literatur der letzten Jahre spielt der Fall Therese Neumann eine große Rolle. Es würden bereits Bücher veröffentlicht, 
It was not the first time that Therese Neumann had filed a complaint against the circulation of photographs. In the summer of 1927, she had accused the same photographer who was on trial in 1932, of circulating, without her approval, the pictures he had taken when she had first started to show the visible traces of physical stigmata. While he had been granted permission to take photographs, one of the major conditions had been that he signed an agreement indicating that he would only use the pictures in accordance with the Pfarramt's instructions.

In her statement of 20 August 1927, Therese Neumann had already forbidden him to sell the pictures and claimed that the photographer was acting against her will and that of the priest. She knew that if the court judged her case to be of cultural significance in the realm of contemporary history, she did not have the right to protest against the circulation of the images. ${ }^{3}$ However, she also believed that the second paragraph of the law concerning the right associated with such images actually supported her case, as their circulation could lead to accusations that she was looking for fame and profit. There was also a risk that her facial features would be used for commercial purposes (to enhance the sale of books and newspapers) and that people who held different opinions, religious or otherwise, would mock her and the Catholic faith and its institutions. Moreover, she claimed that such images increased the number of visitors who came to see her stigmata, and since the pictures had started to circulate, she had received more requests by painters and photographers for similar favours and could no longer cross the street in peace. ${ }^{4}$

While the first court case ended in her favour, the second, in the winter of 1932, concerned who had the right to the circulation of photographs taken by others, and the judge ruled differently. The Neumann family responded by appealing to a higher court. At this stage, Therese and her father, Fernand Neumann, addressed the question of whether or not she was a person of public interest and argued that one only belonged to contemporary history when

die sich ausschließlich mit 'Konnersreuth' befassen." StA, Amtsgericht I Waldsassen 441: Neumann/A.H. Der Oberamtsrichter: Neumayer, Verkündet am 15. November 1932.

3 Reichsgesetz 9.1.07, § 23 I.1: "Ohne die nach § 22 erforderliche Einwilligung dürfen verbreitet und zur Schau gestellt werden: 1. Bildnisse aus dem Bereiche der Zeitgeschichte": "Gesetz, betreffend das Urheberrecht an Werken der bildenden Kunst und der Photographie," January 9, 1907, Reichs-Gesetzblatt 3 (1907): 7-18.

4 StA, Amtsgericht IWaldsassen 440:Therese Neumann, Konnersreuth, gegen A.H., Waldsassen, wegen einstweiliger Verfügung, 1926-1933. This idea of "figures of contemporary history" ("Personen der Zeitgeschichte") was a new feature in the copyright legislation of 1907: private citizens remained in control of the rights to their portraits, while such public figures lost the right to reproduction of their portraits to the photographer. For these legal changes and the impact it had on the image policy of Kaiser Wilhelm II, see Giloi, "Copyrighting," 417. 
"making history" oneself; that is, when one entered "one way or another the public sphere and thus gave the public sphere the right to know one's person." Following this logic, it was clear that Therese Neumann had never entered the public sphere, and had never deliberately become part of contemporary history. On the contrary, the most outspoken characteristic of the plaintiff was exactly her "complete lack of activity." She had done everything to stay out of the public eye, and if she had become a figure of interest, it was against her wishes. ${ }^{5}$

In their opinion, she had a legal right to protest when events of personal, domestic and family life were made public. Moreover, they argued that the pictures - showing her in ecstasy in a distorted or kitschy style - were not simple "natural" images, but were designed to trigger interest and the public's need for sensation. Countering the criticism that more than one million people had already come to see her, their argument referred to the fact that the diocesan authorities were handing out permissions, and therefore that not everyone, and certainly not the entire public sphere, was at liberty to see her: "The circulation of the images, however, created the illusion that the plaintiff had surrendered to the public sphere." ${ }^{\prime 6}$ When it became clear that it was unlikely that she would win this case, Therese Neumann withdrew her complaint. ${ }^{7}$

These two court cases and similar complaints that Therese Neumann and her father filed in the interwar period, offer us exceptional illustrations of the celebrity status of the German stigmatic, the problems it caused and the media that helped to create the phenomenon. This chapter addresses these topics in more detail. Given the celebrity focus of this chapter, many of the cases we will explore relate to the canonical stigmatics - the names that were mentioned as exemplary in the lexica that we studied in the introduction (e.g. Anna Katharina Emmerick, Louise Lateau). However, rather than focus on the specific public personalities, we will look at: (1) how the "machinery" functioned, ${ }^{8}$ or how

5 StA, 440 Amtsgericht/Waldsassen, Therese Neumann, Konnersreuth, gegen A.H., Waldsassen, wegen einstweiliger Verfügung, 1926-1933, Reference to Das Kammergericht Berlin - JW. 1928, S.421 23 Abs. 1, Ziff.1 Kunstgesch. G.

6 "Durch die Bildverbreitung wird das aber illusorisch gemacht und die Klägerin der Öffentlichkeit preis gegeben” statement Neumann's lawyer, 21 April 1933. StA, Amtsgericht I Waldsassen 441: Neumann/A.H.

7 Similar cases were filed and settled in July 1932, most of them ending with the accused promising not to further circulate the images of Therese Neumann. StA, Amtsgericht I Waldsassen 442: Therese Neumann, Konnersreuth, gegen F.K., Konnersreuth, wegen Verletzung des Rechts am Bilde 1932; 443, Therese Neumann, Konnersreuth, gegen F.W., Konnersreuth, wegen Verletzung des Rechts am Bilde 1932; 444, Therese Neumann, Konnersreuth, gegen M.s., Waldsassen, wegen Verletzung des Rechts am Bilde 1932.

8 Morgan, "Review." 
the stigmatics were "surrendered to the public sphere" (changing technologies of printing, development of photography) and the interaction of commerce and devotion; and (2) how their fame built upon their image as "stigmatics." Combining these two aspects will allow us to see how the category of stigmatic "worked" on a commercial/promotional and a devotional level (and, as we will see, these two are not necessarily separate). Thus, rather than stepping into the private quarters of the stigmatics, as we did in the previous chapters, here, we will look into how they, or rather their image, ventured into the world.

\section{Commerce and Devotion}

\subsection{Tensions and Interactions}

As we noted in Chapter 2, scholars such as Chris Rojek and Peter Jan Margry have pointed to similarities between celebrity culture and the cult of saints. ${ }^{9}$ If we think of the use of material culture, it is easy to find examples of this resemblance: fan memorabilia have been compared to relics, and in the writing of fan letters we can see similar tendencies to create virtual intimacy, ${ }^{10}$ as in the cults of saints. Moreover, for celebrities and saintly figures alike, memorial houses/museums have been created documenting the value attached to material possessions and to the locations linked to the deceased. ${ }^{11}$

There is also an alternative interpretation. As demonstrated in the previous chapters, the stereotypical stigmatic often easily fit both profiles: that of celebrity and of "living" saint. In other words, the visual and material cultures surrounding them fit the logic of the two subfields: Catholic devotional culture and celebrity cult. Some of the prototypical stigmatics were the "celebrities" of their time, becoming a marketable commodity, or as Simon Morgan has noted, "the point at which a person becomes a celebrity is the point at which a sufficiently large audience is interested in their actions, image and personality, to create a visible market for commodities carrying their likeness and for information about their lives and views."12

When we look at the work on stigmatics, the scholars who have focused on the interaction between media and popular religion have studied extremely popular twentieth-century stigmatics such as Padre Pio (1887-1968, visible

9 Rojek, Celebrity; Margry, "The Pilgrimage.”

10 Morgan, "Celebrity," 99, 109.

11 Van Osselaer, "Preserved."

12 Morgan, "Celebrity," 98. 
stigmata 1918) ${ }^{13}$ and Therese Neumann (1898-1962, stigmata in 1926). In the case of the latter, Christiane Köppl has suggested that the rapid development of the media in the twentieth century had much, if not everything, to do with the development of her cult (as a "living saint"). Never before could such events be so well documented and promoted. ${ }^{14}$ The press coverage of the Italian Capuchin friar certainly rivalled that of the German stigmatic. As Urte Krass has noted, the swift development of the popularity of Padre Pio and the extent of the fame of the Capuchin father (beyond the local sphere), was only possible due to modern propaganda and marketing methods, in which his fingerless gloves (covering his stigmata) developed into a marketing brand (in the words of Sergio Luzzatto). ${ }^{15}$

In this respect, we might postulate that the fixed dress code that Therese Neumann observed after her stigmatization, a black dress and white headscarf, might be part of her "branding" as well. In both cases, we find efforts to control the public image of the stigmatic. Therese Neumann's court cases against the circulation of her photographs are exemplary and there were similar initiatives in Pio's case. In 1919, the abbot of his cloister in San Giovanni Rotondo forbade the Capuchin friar from making contact with journalists and photographers, and in 1924 he forbade a series of photographs to avoid creating the impression that they were commercially exploiting the cult. Padre Pio had his own personal photographer, so the control in his case was primarily about the

13 Margry, "Merchandising;" Krass, "Stigmata;" Krass, "Kontrollierter Gesichtsverlust." More on Padre Pio in Chapter 7.

14 Köppl, Mystik, 9. In the case of Therese Neumann, two publications seem to have had a major impact on her popularity. Firstly, there was the article that her parish priest published in a local newspaper (Grenzzeitung) shortly after the stigmata first appeared (and before informing the diocesan authorities, 21 April 1926). Warning people to stay away, the article in fact had the opposite effect. Secondly, an article by the famous journalist Erwein von Aretin in November 1927 also provided a boost in Therese Neumann's popularity. Sent to Konnersreuth by the "serious" newspaper, the Münchener Neuesten Nachrichten, he wrote a positive report on his trip that was reprinted no less than four times in the next ten days and translated into 32 languages. Köppl, Mystik, 53 .

15 "wobei die fingerlosen Handschuhe, unter denen er die Wundmale seiner Hände zumeist verbarg, von Sergio Luzzatto zu Recht als sein 'Markenzeichen [...] auf dem christlichen Glaubensmarkt des 10. Jahrhunderts' bezeichnet worden sind." Luzzatto cited in Krass, "Stigmata," 366; 374: "Auch im Falle Pios hat eine 'Medienmaschinerie' dafür gesorgt, dass sich abseits offizieller Kirchenpolitik ein wundergesättigter Kult entwickelte und so mächtig wurde, dass die Kirche ihn schließlich nicht mehr ignorieren konnte." On gloves as 'trademark', see also: Van Osselaer, Rossi, Smeyers and Gabel, Wonde(r), 37. 
selection and creation of the image and - on the level of distribution - a canalization of the mass of images. ${ }^{16}$

The media campaigns around Padre Pio and Therese Neumann both started at the beginning of the twentieth century, and this might create the impression that the commodification and impact of the media on the popularity of a stigmatic are a quite recent phenomena. There were, however, ample examples of earlier cases in which "living saints" were deemed marketable commodities, as we can find references to such commodifications in previous and sometimes lesser known cases of stigmatization. One such example is that of the fourteenyear-old Karoline Beller (1830-?, 1845). When she first started to draw people's attention, a local bookshop owner had 500 copies of her image printed and also published a booklet on her. Unfortunately, the young girl confessed to being a fraud and all of the images and books were subsequently confiscated. ${ }^{17}$

A similar and most probably one of the most extreme examples of commercial investment in a stigmatic is the case of the Belgian Catharina Vingerhoedt, "Heilig Trientje van Stabroek" (1855-1932). When her stigmata (c. 1900) started to attract the interest of visitors, a merchant from Antwerp decided to invest in her case. He first convinced his son to marry a good (and wealthy) friend of Trientje who lived next door to her. After the marriage, the merchant built a sanctuary there, including a Lourdes style grotto and some small shops selling rosaries and the image of Trientje. The parish priest, alarmed by what he saw, warned the episcopal authorities and told Trientje to no longer receive visitors. Her "cult" seems to have diminished after that even though she continued to "die" every Friday. 18

The examples above were primarily cult-related. It is important to note that not all "products" that developed around the stigmatics had a devotional purpose. The sensational aspect of the visible wounds and the ecstatic body seems to have also held sufficient appeal for non-devotees to be willing to pay to see a version of the exceptional bodies for themselves. One of the most telling examples are the wax statues of some of the most famous stigmatics: the Belgian Louise Lateau (1850-1883) and the German Therese Neumann (1898-1962). Neither of these statues was on display in a religiously inspiring setting, with Louise Lateau's image on display in an anatomical museum in

16 Krass, "Stigmata," 378; Krass, "Kontrollierter Gesichtsverlust," 8o (on 6 April 1924: letter to all Capuchin cloisters: forbidding pilgrimages, or any writings or talk about him in public or the spread of his image).

17 On her case, see Chapter 3, and Muhs, "Die Stigmata," 124.

18 Langley, Elfde gebod, 139-154; Cornelissen, "Trientje," Geerts, "Een Stabroekse Pseudo-heilige." 
Liverpool and later in Louis Tussaud's Wax Museum in Blackpool. ${ }^{19}$ In the case of Therese Neumann, in September 1927, the staff of the police station (Gendarmeriestation) of her hometown of Konnersreuth reported that "the Neumann was - with entrance fees - put on display as a wax figure for the Octoberfest in Munich." To make the situation even worse: wax figures of robbers and mass murders were on display next to her. The local legal authorities soon intervened and started a procedure to have her bust removed from the exhibition. ${ }^{20}$

The impact of publications and commercialized images on the popularity of a stigmatic was clearly also a topic of discussion in the nineteenth and early twentieth centuries. ${ }^{21}$ Below, we will address some of the occasions in which the ecclesiastical authorities decided to intervene. Such moments of conflict inform us about the type of media against which they responded - allowing us to glimpse the nature of the media of the time - and their reasons for responding, their fears and points of reference.

\subsection{Monitoring an Expanding Field}

According to Gëzim Alpion and others, fame underwent important denotative and connotative changes as early as in the first half of the seventeenth century with the emergence of newspapers. From the nineteenth century onwards,

19 For the wax figure of Louise Lateau on display as a curiosity in an anatomical museum in late nineteenth century Liverpool, see "Something like a miracle: Louise Lateau," Descriptive catalogue of the Liverpool Museum (1877?), 47-48 (The collection moved to Blackpool in 1938 and was on display in Louis Tussaud's Wax Museum). On such wax figures and their exhibition in museums and at fairgrounds, see Ebenstein, The Anatomical Venus; Kermis of kennis. On the response to celebrity stigmatics like Louise Lateau and stigmata in general in the British Empire, see the ongoing PhD project of Kristof Smeyers. "dass die Neumann auf dem Oktoberfest in München gegen Eintrittsgeld als Wachsfigur zur Schau ausgestellt ist." StA, 4169 Bezirksamt Tirschenreuth, Schreiben der Gendarmeriestation Konnersreuth an das Bezirksamt Tirschenreuth, 24/9/1927; StA, 13038 Regierung der Oberpfalz, Kammer des Innern, "Das Geschäft um Konnersreuth," Grenz-Warte, 1/10/1927 (nr. 117).

21 Polemical press coverage in general will not be addressed in this chapter. For this topic, see Chapter 6. On the influence of such press coverage on the visibility of the stigmatic, see the files on Barbara Pfister in ABSp, Bischöfliches Ordinariat, Älteres Archiv, Nr. 197, letter of Pfarrer F. Weber, 14/1/1891 to the Bishop; letter of Pfarrer Joh. Stamer. Similarly, one of the devotees of the German stigmatic Anna Henle (1871-1950) warned her correspondent not to inform Friedrich Ritter von Lama about her case, for "Annele should not become popular and Ritter von Lama, a zealous promotor of such cases, writes whenever he gets his hands on something." ("Annele dürfe nicht populär werden, u. Ritter von Lama ein eifrigere Förderer solcher Sachen schreibt, wenn er so etwas in Händen hat darüber.") BSB, Nachlass Lama, Friedrich von (1876-1944), Ana 445, Schachtel 2, Brief 5/1/1938, letter to Schmegler. 
thanks to the development of technologies such as the "dye-plate, photography, telephone, phonograph, the roll film, radio, motion pictures," being "famous in the industrialized world gradually came to mean mainly being in the public eye."22 For our focus here, it is not only important to look at the type of celebrity that these media developments created, but also to study the impact of such developments on lived religion.

Episcopal interference in the media of new "cults" was nothing new. As Urte Krass has shown, attempts to control specific media in order to hinder the development of a cult have been reported in relation to other eras as well (e.g. woodcut prints of the new child martyr Simon of Trente, 1472-1475, in the fifteenth century). ${ }^{23}$ What was new, however, was the diversity of "products" and the scale of the reception. News travelled fast and far, and images, booklets and even periodicals on the stigmatics could be produced on a massive scale at relatively low cost. ${ }^{24}$ This also meant new challenges for the ecclesiastical authorities involved. They intervened regularly, and because of the public character of these cults and the enthusiasm for them, so did the public authorities. ${ }^{25}$

Many of the images, texts and other means had devotional purposes and were meant to stimulate religious enthusiasm surrounding the stigmatic and her wounds. As such, it is no surprise that the ecclesiastical authorities of Münster responded to the "fast and wide" circulation of lithographs (Fig. 5.1) depicting the drops of blood from the crown of thorns of the German stigmatic Theresia Winter (stigmata 1844) and the booklet on her visions called Die Dornenkrone mit Biblisch-katholisch-kirchlichen Auslegungen oder das zeigende und zeugende Zeichen in Dorsten bei Münster in Westphalen (The crown of thorns with biblical-Catholic-ecclesiastical explanations or the demonstrating and edifying sign in Dorsten near Münster in Westphalia). ${ }^{26}$ Given its religious content, they complained to the public authorities, arguing that the

22 Alpion, "Media," 541. On the material aspect of this celebrity culture, see Van der Linden, "Medals," 23, "The rise of a public sphere shaped by print culture made new notions of celebrity and notoriety possible. As the century progressed, the rise of a consumer culture and technical innovations - such as the mezzotint printing technique and transfer printing, which allowed images to be printed on ceramics - meant that this culture of celebrity took also a more distinctly material turn (with actors figuring on snuffboxes, tiles etc.)."

23 Krass, "Stigmata," 38 o.

24 For this change in the production process (e.g. mechanization of printing and the spread of wood-pulp paper) and its implications, see Stieg Dalton, Catholicism, 206.

25 Margaret Stieg Dalton has addressed the Catholic views on censorship in the late nineteenth and early twentieth centuries, focusing primarily on questions of morality, Stieg Dalton, Catholicism, 207-209.

26 Dorsten, Verlag von Franz Ahn. 
booklet should never have been approved by the government's censor. ${ }^{27}$ They wanted to stop "the manifold irritations that were created by the brochure that had been spread fast and wide in such a reckless and unlawful way" and remove both Theresia Winter and her father confessor (who was responsible for the publications) out of sight of the public. They asked "in the interest of the Church [...] that the further spread of the brochure would not take place."

In Theresia Winter's case, the verdict was negative, but even when the episcopal authorities were not completely opposed to the stigmatic and what she represented, ${ }^{28}$ too much attention could still be deemed problematic and potentially negative with respect to any ambition of turning the "living saint" into an official canonized one after her death. This seems to have been the case in 1877 when the Bishop of Tournai ordered the return of all photographs of the Belgian stigmatic Louise Lateau (1850-1883). Interestingly, the Bishop had permitted that particular photoshoot himself in order to have photographic documentation of the case (portraits and photographs of the ecstasy), but later feared that commercial misuse could be made of the series by the people who had been involved. ${ }^{29}$

The episcopal authorities, however, not only responded to media that had an outspoken religious purpose. In fact, as several interventions concerning the popularity of Theresia Neumann might show, the ecclesiastical authorities seemed to have feared the impact of entertainment based on the phenomena just as much. For example, in October 1927, the archdiocese warned the government of Oberpfalz and Regensburg concerning a play about Konnersreuth that was about to be staged by the Süddeutsche Volksbühne in Uffenheim, and which had been announced as "new and sensational." It was described as certain to damage the confessional peace and to be regarded as "gross mischief" and a "performance [that] is certainly only intended to serve commercial goals and its own needs."30

27 Münster, LAV NRw. Innere Verwaltung, Oberpräsidium Münster, 123. Tätigkeit des Franziskanerpaters Heinrich Gossler, Fol.63: letter of Gen.Vik. 15/2/1846.

28 "Die vielfältigen Aergernissen, welche diese so unvorsichtiger als unrechtmässiger Weise schnell und weit verbreitete Broschüre bewirkte" "im Interesse der Kirche [...] dass die fernere Verbreitung der Broschüre nicht stattfinden möge." Münster, LAV NRW. Innere Verwaltung, Oberpräsidium Münster, 123. Tätigkeit des Franziskanerpaters Heinrich Gossler, Fol.63: letter of Gen.Vik. 15/2/1846. On the symbolic function of the stigmatic for political causes, see Chapter 6, on their religious meaning see Chapter 3 .

29 On this episode, see Van Osselaer "The Affair."

30 " [...] ein allgemeines Verbot dieses Theaterspieles erlassen, da dies Stück sicherlich den konfessionellen Frieden gefährdet und als grober Unfug bezeichnet werden müsse. Seine Aufführung soll doch gewiss nur gewinn- u. selbstsüchtigen Zwecken dienen." StA, 13038 Regierung der Oberpfalz, Kammer des Innern, Das Erzbischöfliche Ordinariat Bamberg 
Interest in the stigmatics often went beyond the local region and sparked enthusiasm in other dioceses and countries as well. When exponents of the "foreign" stigmatic cults were imported into other dioceses, the bishops of the receiving diocese could respond - and they did. In February 1931, the Konnersreuther Sonntagsblatt created unease beyond Therese Neumann's own diocese. Although there was interest in the stigmatic nationwide (and beyond), when the owner of a bookshop in Trier decided to include the new periodical in his selection, the local episcopal authorities forbade him: ${ }^{31}$ "Since the 'Konnersreuther Sonntagsblatt' concerns itself with the events in Konnersreuth in an exaggerated way, we have to make a negative response to your demand for publicity for the periodical. We also discourage you from spreading such literature, as it influences the population in an unhealthy way."32

Albert Angerer, creator of the Konnersreuther Sonntagsblatt, heard of this verdict and wrote to the Trier episcopal ordinariate himself. ${ }^{33} \mathrm{He}$ claimed that he could not understand why they would not want to fight the irreligious press with a Catholic publication that had been submitted to ecclesiastical censorship and had been approved by the ordinariate of Regensburg. ${ }^{34}$ Moreover, he did not accept the reason that the Trier diocese gave for its rejection (that there were already three Sunday newspapers), ${ }^{35}$ asking whether it did not have more to do with their own stigmatic in Bickendorf. Perhaps they were afraid that by introducing this Sunday newspaper, the interest in this local case might be

an die Regierung von der Oberpfalz \& Regensburg, K.d. I. Regensburg. Betreff: Die Vorkomnisse in Konnersreuth, 22 October 1927. In this respect they resembled the actions of the public authorities concerning the play, "Therese Neumann oder das Wunder von Konnersreuth." StA, 13038 Regierung der Oberpfalz, Kammer des Innern, Bezirksamt Burglengenfeld an die Regierung der Oberpfalz und von Regensburg, Kammer des Innern, in Regensburg, Betreff: Therese Neumann von Konnersreuth, Berichterstatter: Bezirksamtmann Fritzsche, 26 November 1927; 16 February 1928: Strafanzeige; Bezirksamt Burglengenfeld an die Regierung der Oberpfalz und von Regensburg, Kammer des Innern, Regensburg, 14 July 1928.

31 The Konnersreuther Sonntagsblatt existed alongside another weekly paper: StA, 13038, Regierung der Oberpfalz, Kammer des Innern "Die Konnersreuther Zeitung”, Volkwacht $\mathrm{f}$. Oberpf. U. Niederb., 21 October1927, Nr. 242.

“Da das 'Konnersreuther Sonntagsblatt' sich in überspannter Weise mit den Konnersreuther Vorgängen befasst, haben wir auf Anfrage uns gegen die von Ihnen gegebene Reklame für dieses Blatt erklären müssen. Wir raten auch Ihnen von der Verbreitung solcher Lektüre ab, weil durch diese die Bevölkerung in ungesunder Art und Weise beeinflusst wird." ват, BIII.12, 10 Bd.3f, letter to Josef Först, 23 February 1931.

33 BAT, BIII.12, 10 Bd.3f, letter Albert Angerer, Waldsassen (Bayern) 12 March 1931.

34 BAT, BIII.12, 10 Bd.3f, letter Albert Angerer, Waldsassen (Bayern) 12 March 1931.

35 BAT, BIII.12, $10 \mathrm{Bd} .3 \mathrm{f}$, letter Albert Angerer, Waldsassen (Bayern) response to the letter of Angerer 12/3/1931 "braucht nicht revidiert zu werden 4 February 1932: to Gen.Vik." by the Schriftleiter of the K.S. 
rekindled, he conjectured. ${ }^{36}$ The Trier Vicar General did not budge, claiming that they had the right to teach their own devotees and pronounce their views on newspapers. He admitted that it was true, however, that the Bickendorf case made the situation precarious and that this had also been the reason for forbidding a series of lectures on Konnersreuth. ${ }^{37}$ Similar motivations also played a part in the decision of the archdiocese of Munich-Freising to forbid a series of lectures on Konnersreuth in November 1928. The correspondence explicitly mentioned that the decision had everything to do with the Bavarian bishops' attempts to reduce the number of visitors to Therese Neumann, and that this was why they "could not permit such promotional lectures silently mobilizing mass visits." 38

As this overview shows, the ecclesiastical authorities responded to all types of cultural products (including booklets, images, theatre, periodicals and lectures) for various reasons, such as safeguarding the confessional peace and countering ideas that were not in line with religious teachings. What is most important for our discussion here, however, is that by forbidding lectures or the publication of a periodical and the circulation of photographs, they wanted to deflect the interest of the people and avoid accusations of commercialization (just as Therese Neumann did when she pleaded her case in court). The previous examples might create the impression that the episcopal authorities only reacted to products that had a potential commercial aspect, but this was only part of the story.

"Stigmatics" were religiously meaningful to the faithful, and the promotional campaigns that developed around them therefore also fit the visual and material logic of a Catholic culture in which relics played an important role. As such, it is telling that the Archbishop of Mechelen, Du Rousseaux, reported to the Vatican in August 1883 that devotional cards with drops of blood from Louise Lateau were circulating, with the signature of her parish priest vouching for their authenticity, and he asked what he could do about this. ${ }^{39}$ Moreover,

36 BAT, BIII.12, 10 Bd.3f, letter Albert Angerer, 16 February 1932.

37 BAT, BIII.12, 10 Bd.3f, letter to Albert Angerer 2o February 1932.

38 "[...] deshalb nicht dulden, dass durch solche Reklamevorträge stillschweigend zum Massenbesuch aufgefordert wird." AEM, Nachlass Faulhaber, 5945 (1926-32): Therese Neumann von Konnersreuth, Anna Nassl, letter R. Hindringer to Mayrhofer, 15 December 1928. The archdiocese of Bamberg had made a similar decision concerning a series of public lectures on Konnersreuth that could only have "bedauerliche Folgen" among the gullible audience. StA, 13038 Regierung der Oberpfalz, Kammer des Innern, Das Erzbischöfliche Ordinarat Bamberg an die Regierung von der Oberpfalz \& Regensburg, K.d. I. Regensburg. Betreff: Die Vorkomnisse in Konnersreuth, 22 October 1927.

39 Archives of the Congregation for the Doctrine of Faith (ACDF), Archivum Sancti Officii Romani (so), Stanza Storica (St.St.), Lateau, $\mathrm{C}_{4} \mathrm{~F}$ 1, report Du Rousseaux, "Louise Lateau" added to letter 4 August 1883 . 
the fame of Louise Lateau was not only built on the many publications and images of her, but also on the "relics" that were circulating among the faithful that were deemed powerful.

In the following, we want to look at how the fame of these women built on their image as a "stigmatic", addressing two ways in which this fame was established. Given the significance attached to the visibility of the wounds and the ecstasy of the stigmatics (as discussed in Chapter 3), and the important role that visual representations played in the discussions of their precursors ${ }^{40}$ we will examine: (1) the visual promotional material and (2) the practices that developed around the blood relics (such as the devotional cards of Louise Lateau mentioned above).

\section{3}

\section{Capturing Corporeal Mysticism}

\subsection{Portraying Stigmatics: The Creation of a Type and "True" Image}

Although fame is almost by definition linked to a specific individual, focusing solely on the individual aspect would provide only a fragmented view. Therese Neumann, Louise Lateau and the others were famous because they were "stigmatics" and it is this aspect of their fame that interests us here. How did it feature in their promotional campaigns? How was it visualized? In studying this visual aspect caution is needed. As we pointed out in the previous section, not all stigmatic-related "products" had a religious goal, and it is not always possible to define exactly what the motivation was for their creation. Since it is impossible to cover the whole visual production of this period, ${ }^{41}$ we will focus on images that were meant for a broader audience (rather than, for example, drawings included in diaries or letters), ${ }^{42}$ and more specifically on the images that depicted the stigmatics as religiously meaningful (e.g. in contrast to caricatures).$^{43}$ We study the pictures of the canonical stigmatics in which they were presented "as stigmatics" (rather than images of them in a normal state) and that were (or at least could have been) produced on a larger scale (such as woodcut prints, lithographs and photographs/postcards) as part of

40 Davidson, "Miracles," 103: "Artistic representation played an important role in the diffusion of the theme of Francis' stigmata, and opposition to the stigmata often took the form of opposing such presentations or mutilating those that already existed."

41 For example, depictions of houses, rooms, churches, family pictures.

42 See, for example, Kadoc, Jezuïeten, 4.2.1.9. Archief van het provinciaal bestuur. Spiritualiteit en devotioneel leven, 2261: report on Anna Katharina Emmerick (1813).

On caricatures, see the next chapter. 
a promotional campaign. To be marketable and religiously meaningful, they needed to be specifically recognizable as a stigmatic.

Studies on the representation of stigmatization have primarily focused on St Francis and Catherine of Sienna and have discussed the visibility of their wounds, the logic of the stigmatization (mirroring or imitating Christ's wounds) and the role of such images. ${ }^{44}$ While there seems to be little doubt that the iconography of St Francis influenced the twentieth-century representation of Padre Pio (similar scenery, pose), ${ }^{45}$ St Francis and Catherine of Sienna do not seem to have played a similar role as models for the visual representation of "our" stigmatics. In the depiction of the medieval saints, the moment of stigmatization was a recurring theme ${ }^{46}$ with rays of light emerging from a crucifix and marking the saint's body. When we look at the pictures of three of the nineteenth-century canonical stigmatics that were circulating during their lifetime, it is not this moment that is represented; rather, we see them on a chair or in bed - as grabataires ${ }^{47}$ - with the furniture indicating a domestic setting. ${ }^{48}$ By not focusing on the moment of stigmatization and instead showing the viewers the stigmatic in the intimacy of her home with visitors present, the producers were visualizing an actual visit to a stigmatic. In a way, this iconographic tradition presented the modern stigmatic as approachable and recognizable since many of the viewers would be familiar with this type of setting. Moreover, images such as these showed how the divine could intervene in everyday life.

The prominence of the stigmata in these pictures tallies with the popular perceptions of sanctity, in which wonders and their corporeal manifestations

44 Belting, "Saint Francis"; Vauchez, "De la stigmatisation," 16.

45 Krass, "Stigmata," 376.

46 See e.g. Savelsberg, Franziskus.

47 Depicting the stigmatics as bedridden, as "grabataires," enhances the similarity of their cases with those of the other miraculous bodies: the nineteenth-century fasting women who were also depicted lying in bed (Sarah Jacob, the Welsh fasting girl, Mollie Fancher). Nevertheless, while inedia was often attested to in relation to our stigmatics, it is clear from these pictures that the stigmata were considered the central feature. On the fasting girls, see Vandereycken, From Fasting Saints; Jacobs Brumberg, Fasting Girls.

48 Louise Lateau's representation changed from her sitting on a chair to lying in bed (when she became a grabataire). For Anna Katharina Emmerick, see e.g., "Lewald hatte auf die Kappe das Bild der Seligen, wie sie stygmatisiert im Bette gesehen wird, geklebt. Solche Bilder habe ich schon viele gesehen; sie sind zu Lebzeiten der Cath. Emmerich oder bald nach ihrem Tode gemacht und beweisen die Beruhmtheit, welche sie schon damals hatte," Gedenkstätte Anna Katharina Emmerick (GAKE), "Abschrift” Dokumente über die Sachen aus der Nachlassenschaft der gottsel. Anna Katharina Emmerick, p.32 nr.88. See also the images on display in the Gedenkstätte in Dülmen and the drawn copy included in Wegener, Das wunderbare innere und äußere Leben (1912), 339. 
played a central role. ${ }^{49}$ When we look at the woodcut prints of Anna Katharina Emmerick that were created during her lifetime or shortly after her death (in 1824), the imitative stigmata on her hands and feet and the figurative stigmata (crosses on her chest) immediately draw attention (Fig. 5.2). To achieve this effect, the sheets are pulled back (so we can see the bare feet and wounds) and the stigmata on the chest are even visible through her clothes. ${ }^{50}$ In this respect, the pictures are similar to those of Maria Domenica Lazzeri $\left(1815^{-1848}\right.$, stigmata 1834), where we also see her bare feet. ${ }^{51}$ (See Chapter 1, Fig. 1.5).

Contrary to Lazerri's image, however, in the Emmerick prints, the iconography includes explicit references to the supernatural, with the all-seeing eye in the top-right corner and the Y-shaped crucifix (said to have inspired one of the figurative wounds on Emmerick's chest) in the middle as a mediator between God and the stigmatic. The stigmata are stylized versions of the wounds, shown as round dots. Comparing these pictures with those of Louise Lateau in the late 186os (shortly after her stigmatization in 1868), we can detect some similarities. In a print by R. Landucci (Fig. 5.3), the young stigmatic is depicted sitting on a chair, with the domestic context even more explicit (with a window, open door, the silhouette of the village in the background and people entering the room), and the eyes of the beholder are immediately drawn to the stigmata, from which blood is dripping in dramatic red. Similar to Emmerick's pictures, there are rays of light hinting at the supernatural origin of the wounds. ${ }^{52}$

Landucci's print is quite similar to the picture on display in the Museum of Louise Lateau in Bois d'Haine: both carry the title "Miraculous souvenir of Louise Lateau" ("Souvenir miraculeux de Louise Lateau") (Fig. 5.4), but in the latter picture the only visitor is a cleric. The divine inspiration is made even more explicit, as a cloud and small angels with wings hint at heaven. ${ }^{53}$ In both pictures, Louise Lateau is shown barefoot, with the visible, bleeding stigmata on her feet and blood dripping from a side wound through her dress, while her eyes are turned towards heaven as if in ecstasy. The iconography resembles that of another "Souvenir miraculeux de Louise Lateau," created by Dossseray

49 Krass, "Stigmata," 365 . At this point in the book, it almost seems self-evident that the visible stigmata were such a dominant feature in the representation of the stigmatics, but it should be remembered that the importance of the visual stigmata in the nineteenth century stood in stark contrast with the previous era, as was the prominence given to stigmata as a defining feature of a specific subset of mystics.

Scholz, "Anna Katharina Emmerick," 23-24.

$51 \quad$ Höcht, Träger, 332, 337.

52 Antwerp, Ruusbroec Institute, Collectie Engelen, Heiligen en begenadigden, Anna-Louiza Lateau, $\mathrm{H}_{4}$, R. Landucci, Rue Blaes - a lithographer and book printer active in the second half of the nineteenth century.

Picture on display in Maison Louise Lateau in Bois-d'Haine. 
in 1869 (Fig. 5.5), but while the bare feet, bleeding side, eyes and domestic setting are comparable to the other two pictures, there is no hint of the divine origin: no rays of light, angels or clouds. ${ }^{54}$ Both the Dosseray and the Landucci prints include a brief text helping us "read" the image. They are quite similar and include a laudatio on Louise Lateau's active involvement in the care for the sick during the cholera epidemic, as well as a reference to the numerous visitors and encouragement for the viewers to go and see for themselves.

Do the similarities between the promotional pictures of the stigmatics imply that all prints looked the same? No, but we do want to argue that by the start of the twentieth century, an image could easily be read as a picture of a "stigmatic" if it featured a woman with blood on her face, or bloody wounds, in a domestic setting, and perhaps even in the presence of visitors. ${ }^{55}$ By the start of the twentieth century, a visual stereotype of a "stigmatic" had developed that had little to do with the ways in which St Francis or Catherine of Sienna had been depicted in the previous centuries. ${ }^{56}$ This does not mean that there were no phenomenological differences. On the contrary, there seem to have also been subtypes, with the head bandages of Anne Katherina Emmerick becoming a model for the representations of Viktoria Hecht and Clara Jung, for example; and the kneeling and praying position of Maria von Mörl possibly inspiring the image of Anna Henle and its selection for the front cover of one of her semi-hagiographies.

Although the fame of these women built largely on their reputation as a stigmatic and they were visualized as such, their celebrity and/or saintly status was linked to their individual case. As a result, the images usually mentioned more specific information on the stigmatic, such as the name and sometimes the date, location or a short description. ${ }^{57}$ The pictures also included hints; for example, it was certainly not a coincidence that the miraculous souvenirs of Louise Lateau referred to her work as a seamstress through the inclusion of a sewing machine (in the Dosseray and Landucci prints) or a needle cushion. In fact, the caption for the Dosseray image of Louise explicitly indicated that

54 "Souvenir miraculeux de Louise Lateau" (Dosseray 1869). Bruxelles, Koninklijke Bibliotheek (KBR), Prentenkabinet, S.III.102188, Dosseray 1869.

55 See e.g. the pictures of Rosalie Put, Anna Henle and Clara Jung and others in Höcht, Träger.

56 On the development of a basic type, see Priesching, Maria von Mörl, 407 and 273, on the institutionalization of von Mörl as a process of typification (Typisierungsprozess).

57 For example, the two images of Anna Katharina Emmerick on display at the Gedenkstätte in Dülmen carry the caption "Jungfer Anna Catharina Emmerich zu Dülmen," "Jungfer Anna Catharina Emmerich gewesene Chorschwester zu Dülmen.” 
it had been made based on real life observation. ${ }^{58}$ The idea of a "true likeness" seems to have raised the status of the images, and the public's eagerness for these seems to have only increased when new techniques such as photography developed, combined with the celebrity snapshot culture. ${ }^{59}$

There was, however, also another benefit of the new visualization technique. Photography was seen as a documentary medium, ${ }^{60}$ with photographs considered able to capture the "proof" that in the previous decades could only be observed by those visiting the stigmatics and seeing their wounds and ecstasy with their own eyes. ${ }^{61}$ The logic of the representation of the wounds changed throughout the period under discussion. In the Anna Katharina Emmerick prints, the stigmata were dots, an indication rather than a depiction of the wounds. ${ }^{62}$ The photographs of Padre Pio circulating after 1919 were characteristic of the bloody realism befitting an era of publicity and public relations. ${ }^{63}$ Film had the same documentary reputation and in Therese Neumann's case, some contemporaries suggested that the reason why the German stigmatic refused a lucrative deal for a movie about her was the fear that she might be found to be a fraud. ${ }^{64}$

The "true" image, however, was not always what one wanted to see. A welldocumented example of such a case are the photographs of Louise Lateau taken in 1877. They are one of the earliest examples of contemporaries attempting to capture the ecstasy of a stigmatic on camera. When the Jesuit father who took the photographs later commented on this session in his diary, he mentioned that he had felt ill at ease when he saw her in ecstasy, acting "like an automaton," in a manner "reminiscent of a nervous illness." He preferred

58 "Reproduit d'après nature par Dosseray."

59 On the evolving photographic techniques and the discussions that resulted from these new developments (e.g. the snapshot), see Giloi, "Copyrighting," 419.

6o On this, see the comments by Berlanstein ("Historicizing," 71), "The presumed authenticity of the photo was greater than that of earlier engravings or lithographs and allowed fans to feel that the 'owned' their star."

61 In Padre Pio's case, the photographs in themselves became proof of the saintly character of the Capuchin friar: rumour had it that if he did not want to be photographed, he was not visible in the picture, Krass, "Kontrollierter Gesichtsverlust," 82.

62 See the comment by Freeman on the depiction of the stigmata of St Francis up until the modern period, there is no striving for realism, "eerder aangeduid dan afgebeeld," Freeman, "De verbeelding," 199.

63 Freeman, "De verbeelding," 199; Krass, "Stigmata," 375.

64 вSв, Westermayr, Johann Baptist (1884-1950), Theologe, Ana 338, Akten und Korrespondenzen über die Stigmatisierte Therese Neumann von Konnersreuth, IV. Unsignierte Texte, Texte von Dritten, Konnersreuth und Silva-Mello, post 1936, p. 7. Therese Neumann u. die Filmgesellschaft. 
the stigmatic of Bois d'Haine in her natural state. ${ }^{65}$ His unease is understandable when we realize that such photographs could be read as proof of hysteria rather than sanctity. In studies such as the Iconographie photographique de la Salpêtrière, Louise Lateau was mentioned as an example of certain stages of a hysterical fit (such as the crucifixion pose). ${ }^{66}$ The photographed, "real" ecstasy of Louise Lateau was not an image the promotors wanted to spread. However, this never really had to be discussed, for - as noted above - the bishop recalled all of the photographs.

Thus, it appears that the development of new techniques (photography, film, autotypy) not only allowed for important changes in communication (speed and scale) but also enabled shifts in the use of images to create the reputation of the stigmatic. We should be careful, however, not to make this a dominant, all-eclipsing narrative. The format and shape of the wounds of some of the stigmatics were documented with great care before the development of photography ${ }^{67}$ Furthermore, it seems as though different markets had other expectations. At least that is the impression that an article by a contemporary of Therese Neumann leaves. The author noted that the American press not only included an image of the "miracle girl" (as in Germany), but also a close-up of her hands, with a clear view of the stigmata, apparently a "really American practical" thing to do. ${ }^{68}$ Nevertheless, whatever differences these changing visualization techniques entailed, what remained constant throughout the period was the prominent role of the stigmata in these popular depictions of the stigmatics that were not authorized by the Church. As we will see below, this was less likely to be the case in the "official" circuit.

\subsection{Collectable and Venerable: Prints, Blood and "Relics"}

Focusing on the visualizations might create the distorted impression that the fame and the concomitant image of a stigmatic was imposed upon the faithfulas intended by producers and promoters. This structuralist view omits two important players: the stigmatic and the devotee. As this book concerns the

65 Van Osselaer, "The affair."

66 “[... comme une automate [...] cela ressemblait tant à une maladie nerveuse [...] Vénération donc, me disais-je, pour Louise naturelle": "Mémoire sur les photographies de Louise Lateau," Kadoc, Jezuïeten, 4.2.6, 1595 Ernest Lorleberg, 14475 "Mémoire sur les photographies de Louise Lateau avec supplément de quelques-unes de ses paroles dites à l'auteur." See Hervé Guillemain on the clergy's pathologizing of strange religious phenomena, Diriger les consciences, 138; Didi-Huberman, Invention, 33; Gilman, Seeing, 164, and "The image," 352 .

67 Detailed drawings of the wounds in books such as Imbert-Gourbeyre, Les Stigmatisées, II, 35.

68 "[...] echt amerikanisch-praktisch" article Erwein von Aretin November 1927 cited in Köppl, Mystik, 53 . 
stigmatics as a type rather than the individual personalities, we will not address their own influence on the construction of their image here, but we will address the devotees' role in the process. Sanctity is in the eyes of the beholder, as Caciola noted, ${ }^{69}$ and so is fame, we might add. The ways in which the faithful engaged with the visual and material for example, enhanced and supported their fame as celebrities and "living saints" (we will address the post-mortem situation further below). In addition, a photograph of Padre Pio was meaningful to the devotees because it carried his image, but it was their use of it (while praying for a sick person) that enhanced the fame of the Capuchin friar - when thaumaturgical powers were witnessed. ${ }^{70}$

Thus, if we want to gain an idea of how the fame of the stigmatics worked and how their image as stigmatics was constructed, we need to look into what people did and felt. ${ }^{71}$ As Gordon Lynch suggested, referring to the work of David Morgan (2009): "The study of religious visual culture is therefore not simply the analysis of religious images, but the religious practices of seeing, through which these images become a part of people's everyday worlds."72 Scholars such as Urte Krass have shown how the large scale on which devotional pictures (e.g. a devotional card with a photograph of Padre Pio) were distributed did not diminish their cult value. Their mass production did not undermine the aura of the stigmatic and they were often used in prayer. ${ }^{73}$ This use of visual means in prayer illustrates the importance attached to the visual dimension in Catholicism and thus reflected devotional traditions. ${ }^{74}$

Here we want to focus on an aspect of the stigmatic's cult that seems to have been a particular feature of their popularity: the bloody imprints of their wounds and the practices that developed around these "relics." 75 In these practices, the tactile element was as important as the visual. As we noted in Chapter 3, the faithful perceived the visible wounds of the stigmatic as proof of the supernatural. The importance attached to the visual not only resulted in

69 Caciola, "Through a Glass," 304.

70 On the thaumaturgical images of Padre Pio, see Krass, "Kontrollierter Gesichtsverlust," 82.

71 Morgan, "Introduction," 11-12: "Belief should not be understood as coming only before such things as the veneration of relics or the ecstatic drudgery of pilgrimage, but as being constituted by them. People do what they want to believe. They make belief in things they do."

72 Lynch, "Religion," 550.

73 Krass, "Stigmata," 377. What Eva Giloi has noted about the photographs of the German Emperor also seems to be true for those of our stigmatics, the widespread use of the picture did not undermine their aura, Giloi, "Copyrighting," 41.

74 Borutta, Antikatholizismus, 183 (on the importance of visual culture).

75 On the importance of material culture for the study of lived religion, see e.g. Morgan, "Materiality," 56, 59 . 
their prominent presence in the depictions of the stigmatics, but also in what has been called a "fetishism" of the wounds. ${ }^{76}$ In the case of the German stigmatic Theresia Winter, this interest materialized in a publication called the Die Dornenkrone (Crown of Thorns, 1846) - a booklet that, as we discussed at the beginning of the chapter, was condemned by the Church authorities - and in a lithographic reproduction of the bloody imprints that Theresia Winter's head wounds left on the bandages (Fig. 5.1). ${ }^{77} \mathrm{~A}$ Berlin newspaper criticizing the "ultramontane scheming" of Theresia Winter's spiritual guide (who published the print), mocked the commercial aspect of the production of the images, meant for those "who could not go and see for themselves."78

The article was clearly written from an anti-Catholic perspective, but it does seem to hold some truth. The imprints of the wounds indeed functioned as an additional form of confirmation and as some sort of "multiplicator" of the experience. At least, this is what we can assume after comparing this material output to that of other cases. While it was quite exceptional to have a lithograph made of the bloody imprint, the practice of collecting the imprints of the bloody wounds had already been attested to in earlier cases. Contemporaries of Anna Katharina Emmerick (stigmata 1812), for example, described how when the news of her stigmata spread, and people started talking about her, those who were lucky enough to go and see her in Dülmen brought back confirmation: "They showed imprints on canvas (Leinwand), silk and paper of the crucifix [the figurative wound on her chest, TVO] and the wounds and sent them to those who could not see and hear for themselves."79 The imprints were not necessarily obtained with the permission of the stigmatic. Therese Neumann, for example, notified the gendarmes of Konnersreuth in 1927 that an unknown individual had entered her room, lifted her head scarf and "rubbed something on her cheek and the heart wound, probably a piece of cloth to get some blood." When the intruder attempted to do the same thing with her feet, the stigmatic started kicking. Apart from this, so she said, she was not able to defend herself

76 Vinken, "Via crucis," 21.

77 "Die Ansicht eines Tuches vom 2 Januar 1846 mit 115 Bluttropfen," LAV NRW, Staatsarchiv Münster, Kreis Recklinghausen, nr.36. Dornenkrone Lithografie.

78 LAV NRW, Staatsarchiv Münster, Kreis Recklinghausen, nr.36. Königliche priviligierte Berlinische Zeitung, 31 January 1846, pp. 5-6 (Fol.67b).

79 "Man zeigte Abdrücke auf Leinwand, Seide und Papier von dem Kreuze und von den Wunden und verschickte sie an diejenigen welche nicht selbst sehen und hören konnten" LAV NRW, Regierung Münster, nr. 17709, Die Wundergeschichte der stigmatisierten ehemalige Chorschwester Emmerich zu Dülmen, 19 February 1817: "Auch etwas über die Erscheinungen bei Anna Catharina Emmerich, Chorschwester des aufgehobenen Klosters Agnetenberg in Dülmen." 
because of the fatigue she always felt on Fridays. ${ }^{80}$ Why would someone be so keen on gathering such souvenirs?

This eagerness tallies with the perception of the stigmatic as a "living saint" and the stigmata as a "wonder." Touching the stigmatic's body with some fabric not only produced a souvenir of the visit but also a kind of "relic."81 The mediating power that the stigmatic was thought to possess could "rub off" on whatever material (paper, textile, etc.) had touched her body. As we noted above, devotional cards with the blood of Louise Lateau were circulating in different strata of society (e.g. among domestic servants). ${ }^{82}$ A letter of the Belgian queen Marie-Henriette on 28 September 1868, relates the illness of her son and how she had put "the imprint of the wounds of Louise Lateau on the heart of our beloved little patient. He united his sufferings with that of Our Lord Jesus Christ on the Cross." 83 Given the fact that this was a letter to the Archbishop of Mechelen, Cardinal Dechamps, and Louise Lateau was by no means a Church-approved saint and still very much alive at the time, it is rather remarkable. Such cards with drops of Louise Lateau's blood continued to circulate during the rest of her "career" as a stigmatic.

It is interesting to note that a system of authentication also seems to have developed, with Louise Lateau's parish priest signing the cards as proof of their authenticity. ${ }^{84}$ In other words, these unofficial relics were approved by a

8o "[...] ferner mit etwas auf der Wange und auf der Herzwunde gerieben, vermutlich mit einen Tüchlein um Blut zu bekommen." StA, 4169, Bezirksamt Tirschenreuth, Schreiben der Gendarmeriestation Konnersreuth an das Bezirksamt Tirschenreuth, n. 39: 26 February 27. She was also missing a prayer book, socks and the bandages for her feet, but the stranger had left a five mark note under her pillow as compensation, so there seems to have been no intention of stealing.

81 On the different types of relics, see Walsham, "Introduction," 9-10.

82 Introductory letter from Du Rousseaux, 3 August 1883 , and letter from Cmtsse de Liminghe, 26 June 1883 added to ACDF, so, St.St., Lateau $\mathrm{C}_{4} \mathrm{~F}$ 1, report by Du Rousseaux, "Louise Lateau" added to letter 4 August 1883.

83 "L'empreinte des plaies de Louise a été posée sur le cœur de notre cher petit malade. Il a uni ses souffrances à celles de Notre Seigneur Jésus-Christ sur la croix, et j'attends un mot de vous pour restituer l'image ensanglantée." Kadoc, Archief Redemptoristen, NoordBelgische Provincie 3·3.2.3. Victor Auguste Dechamps, 1477 Queen Marie-Henriette (18361902). Letters to Dechamps (1867-1882), letter of 28 September 1868.

84 It is unclear to what extent this was intended to mirror the circulation of "official" relics of "real saints" that had letters of episcopal authentication. When the newly appointed Bishop of Tournay, Mgr Du Rousseaux, wrote to Rome about the situation with Louise in 1883 (the year of her death), he complained about the small "industry" that had developed around the bloody relics: "We believe we need to signal a practice of the parish priest. He distributes images and pieces of cloth with the blood of Louise. On those images, he writes a few words and puts his signature [...] They also distribute images signed by Louise." "Nous croyons devoir encore signaler une pratique de M. le curé. Il distribue 
member of the clergy. The cards and textile fragments continued to circulate after her death. A small collection of miracles attributed to her refers to the healing power of these relics in stories from 1888 and 1914. ${ }^{85}$ Most of the imprints on the devotional cards and cloth were "mere" drops of blood. In some cases, however, the imprints were small "miracles" in themselves, with bloody drawings of objects such as a crucifix, a heart or the torture instruments used in Christ's Passion. ${ }^{86}$ As a sign of the "divine origin" of the wounds, they were cherished by the faithful long after the death of the stigmatic.

As the above examples have shown, the religious practices developing around the stigmatic were tactile as much as they were visual. A relic had to touch the body of an ill person in order to exert its powers, and it had to have touched the stigmatic first or have been marked with her blood. The spread of such relics enhanced the fame of the stigmatic, and if such relics proved to be powerful, the fame of the stigmatic grew.

Until now, we have primarily focused on the ways in which the fame of the stigmatic as such spread during their lifetime. While we will address the postmortem reception more elaborately in the Chapter 7 (on the response of the Vatican), in order to understand the visual and material aspects of the stigmatic cults, some elements must also be addressed here. With respect to the religiously inspired material, the post-mortem production and consumption of the stigmatic's fame was quite similar to what occurred during her lifetime.

des images et du linge tachés du sang de Louise. Sur ces images, il trace quelques mots et appose sa signature. [...] On distribue aussi des images signées de Louise." Introductory letter from Du Rousseaux, 3 August 1883, and letter from Cmtsse de Liminghe, 26 June 1883 added to ACDF, so, St.St., Lateau $\mathrm{C}_{4} \mathrm{~F} 1$, report by Du Rousseaux, "Louise Lateau" added to letter 4 August 1883 .

85 Archives du Séminaire de Tournai (AST) - Louise Lateau, I.4. Faveurs et guérisons obtenues par l'intercession de la Servante de Dieu, LL (manuscrit original écrit à Boscombe le 29 janvier 1938). Pages écrites à l'adresse des amis de Louise et des paroissiens de Bois-d'Haine, e.g. in 1888, and 1914; on the thaumaturgical power of a cap worn by Anna Katharina Emmerick with large drops of blood: BAM, Emmerick/Hensel, 40. Stimmen, nr. 11. Witwe Gertrud Hilgenberg, November 1887.

86 See e.g. ABSp, Dokumentation Barara Pfister $\mathrm{S}_{5}, \mathrm{M}_{7}$ Protokolle über Zeugenaussagen, the testimony of Schw. Cäcilia vom h.H. Jesu, geb. Schäfer von Wattenheim, 26/71938, Carmel. Himmelspforten, See e.g. such figurative imprints in: Imbert-Gourbeyre: Les Stigmatisées, II, 45: Palma Maria Matarelli ("photogravure"), 103-104. 
If the enthusiasm for the stigmatic endured beyond her death, as, for example, in the case of our canonical stigmatics, relics continued to circulate and be used in prayer. New types of relics also developed, such as body parts or material souvenirs from the stigmatic's grave (such as sand or leaves), which became part of the "circuit." 87 Miraculous cures attributed to the stigmatic's relics were carefully listed in the hope that one day they might be used in processes of beatification or canonization. These often resulted in ex-votos on the grave of the stigmatic, a religious material culture that confirmed the saintly status of the stigmatic. ${ }^{88}$ In addition, images and books on the stigmatics continued to circulate and were used in promotional campaigns. ${ }^{89}$

As had been the case during their lifetime, the episcopal authorities monitored what was written and intervened when they deemed this necessary. ${ }^{90}$ The commercial aspect also remained important, as did the idea of the "true image." One concise example of both aspects is the story of a bankrupt photographer who, 50 years after the death Anna Katherina Emmerick (1774-1824), wanted to make good use of this renewed enthusiasm. He used an image of Maria Magdalena Postel (from Paris, founder of the Christian schools of charity) on a card, adding the line: "true representation of the divine ('gottselige') A.K.E., born on 8 September 1774 in Flamske near Coesfeld, died on 9 February 1824 in Dülmen." According to a commentator in 1924, this forged image shows how the devotion to Emmerick was still very much alive at that time and was popular enough to be commercially exploited..$^{91}$

In a few cases, for example those of Louise Lateau and Anna Katharina Emmerick, the devotees' ambition to raise the status of the stigmatic from a popular saint to one officially approved by the Catholic Church stimulated the

87 See, for example, вам, Emmerick/Hensel, 40. Stimmen, nr. 7. Wilhem Overhage; for the history of the head of Louise Lateau as a relic, see: https://stigmatics.wordpress.com/ 2018/og/23/how-to-hunt-a-skull-in-five-steps/.

88 See the graves of e.g. Louise Lateau (previous condition), Clara Jung.

89 See e.g. the tour by Hunkemöller to promote the case of Anna Katherina Emmerick in the United States. One of his means of campaigning was the circulation of a small booklet about her. BAM, Emmerick/Hensel, 45. Kaplan Hunkemöllers Werbereise für Katharina Emmerich in Nordamerika 1923/24: Korrespondenz, Zeitungsauschnitte u.a., c. 1921-1924.

90 See e.g. the censoring of the post-mortem books: ABP, OA Varia I 17 b II Maria Beatrix Schuhmann, PAN, letter Wilhelm Maier, 10 August 1914; AAM, Verschijningen, 20. Lucie Schmit-Klaer; rejection Van Roey of manuscript: "Vie de Madame Klaer, glorieuse Servante de Dieu."

91 "Wahre Abbildung der gottseligen A.K.E., geboren am 8. September 1774 zu Flamske bei Coesfeld, gestorben am 9. Februar 1824 zu Dülmen." EBAP, Nachlass Louise Hensel (17981876), Lehrerin, cutting, Hans Hüer, "Das Bild der Anna Katharina Emmerick", Westf. Heim. Kal. 72 (Münster), 66-68. 
creation of a small museum..$^{92}$ On display were, and still are, the objects that had once belonged to the stigmatic, but also the cultural products (books and pictures), such as the those discussed above. Recreating, or rather staging, the stigmatic's home (Maison Louise Lateau in Bois d'Haine) or room(Gedenkstätte Anna Katharina Emmerick in Dülmen), these buildings are yet another aspect of the stigmatic's promotional campaign. The carefully selected objects, texts and images support the idealizing narrative, but also show the care with which the devotees preserved the objects that had once belonged to the stigmatic. In the case of the Emmerick Gedenkstätte, the creation of the collection is exceptionally well documented. A catalogue, started in the late 1870 os when the first initiatives were taken, includes a small biography explaining many objects in the collection. The preservation of these often inexpensive, everyday objects, such as a coffee cup, shows the depth of the veneration of the previous owners and the ambition of the promotors to once again use material culture to stimulate the fame, here the fama sanctitatis, of the stigmatic. ${ }^{93}$

This does not mean that the "image" of the stigmatic remained the same. As we will see in the Chapter 7 , the popular perception of sanctity, with its focus on the miraculous, differed from those aspects the Catholic Church wanted to promote as "saintly" - which focused on heroic virtues and an exemplary life. In the case of Louise Lateau, the images that set the tone in her post-mortem promotion were nothing like the three versions of the "miraculous souvenir" we discussed above. There were two main images that played an important role in her post-mortem visualization. One was based on a portrait painted by Alexandre Thomas in 1876, which showed the stigmatic of Bois d'Haine in a calm state contemplating the crucifix, with only a small trace of the stigmata. In 1885 , only two years after the death of Louise Lateau, a portrait based on that painting was included in Souvenirs de Bois d'Haine, and variations on the theme can be found on her devotional cards. The other image of her that recurred was a "natural" photograph (one of the outcomes of the 1877 session discussed above), in which she is wearing gloves. The stigmata do not immediately catch the eye in either of these visual traditions. ${ }^{94}$

\footnotetext{
92 Van Osselaer, "Valued."

93 GAKE, "Abschrift" Dokumente über die Sachen aus der Nachlassenschaft der gottsel. Anna Catharina Emmerick.

94 For a similar change in tone and also some creativity with older images, see the changing representation of Taigi and Canori Mora, who developed from mystics into good Catholic housewives, see Van Osselaer, Rossi and Graus, "Virgin mothers."
} 
A report by the Konnersreuth Gendarmerie on Therese Neumann of 1 July 1926 notes how the German stigmatic was venerated by many of her visitors (80-100 a day, among which were many foreigners, especially Americans), who often asked for her signature on pictures ("Bildchen"). Therese, so the report read, no longer signed them, as her parish priest had forbidden her to do so. ${ }^{95}$ This points to a practice which exemplifies celebrity cult, the hunt for autographs of famous people. In this case, the person in question was a German stigmatic, perceived as a "miracle girl" by many of her contemporaries. The phenomenon of autograph hunting adequately illustrates how the practices surrounding celebrities and "living saints" could be quite similar, as was the material and visual culture surrounding them. The devotional and commercial frequently overlapped and caught the eye of the episcopal and public authorities.

The hunt for Neumann's signature also shows how the creation of fame was a co-constructive process; the "consumers" were as actively involved as the "producers" of the promotional material - in fact, a distinction between the two in this regard might appear arbitrary. As the lawsuits concerning her photographs illustrate, it was difficult to control one's public image. New media, such as photography, offered new possibilities but also brought new challenges, given the speed with which images could be produced, the number of copies that could be made and the scale at which they could be circulated. The fame of a stigmatic could easily travel beyond the local region, and the concomitant cultural output during their lifetime seems to have built largely on the image of the stigmatic as a "living saint" with bodily gifts, and on a fetishism concerning the stigmata. The images of the stigmatics that we discussed in this chapter as well as the devotional cards and textile fragments with their blood, built upon and confirmed the idea of the stereotypical "stigmatic," the young woman with visible stigmata who received visitors at home. However, the emphasis changed after the death of the stigmatic, for, if those left behind wanted official recognition for their "living saint," the mystical epiphenomena had to be minimized. For political campaigns, however, as we will see in the next chapter, the stigmata were allowed to feature in all their glory.

95 StA, 13038 Regierung der Oberpfalz, Kammer des Innern, Gend. Station Konnersreuth an das Bezirksamt in Tirschenreuth, 1 juli 1926: Betreff: Die Erscheinungen an der ledigen Schneidermeisterstochter Theresia Neumann von Konnersreuth. Similarly, it is telling that one of the schemes that criminals developed relating to the massive interest in Therese Neumann was the forgery of her signature on the photographs of her that were circulating. 


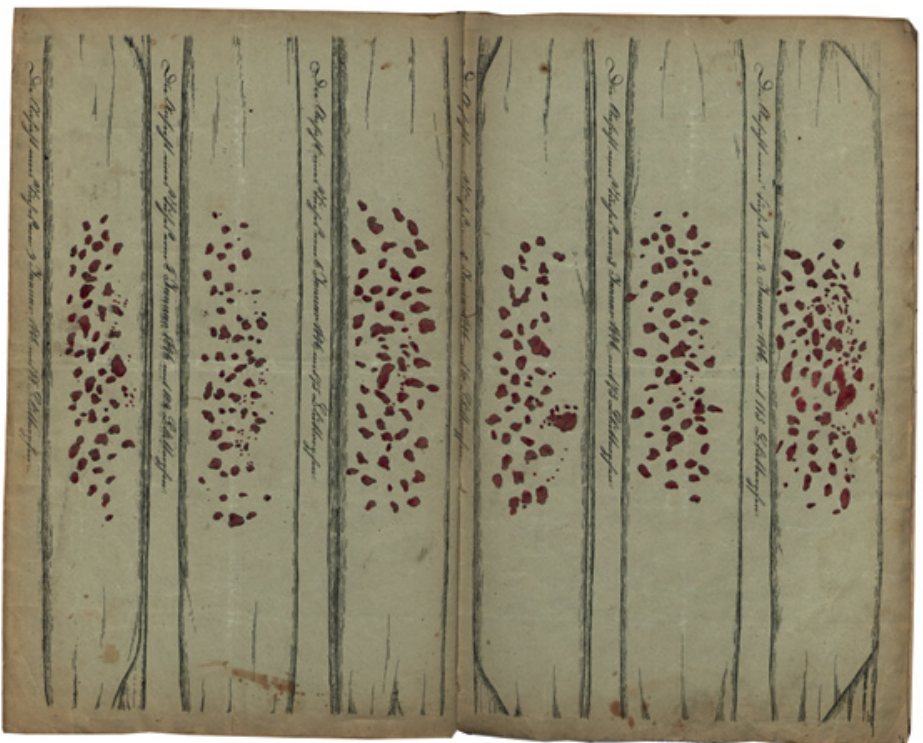

FIGURE 5.1 "Die Ansicht eines Tuches vom 2 Januar 1846 mit 115 Bluttropfen" LANDESARCHIV NRW ABTEILUNG WESTFALEN (MÜNSTER) STAATSARCHIV MÜNSTER, KREIS RECKLINGHAUSEN, NR.36. DORNENKRONE LITHOGRAFIE (CC-BY-NC-SA)

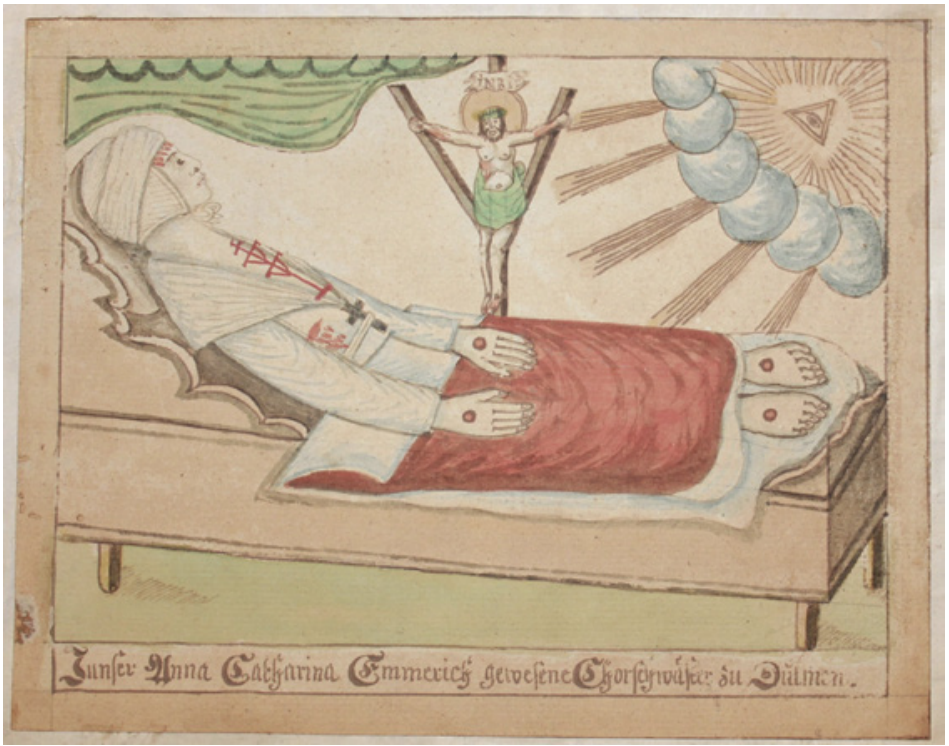

FIGURE 5.2 Anna Katharina Emmerick (woodcut print) DÜLMEN, GEDENKSTÄTTE ANNA KATHARINA EMMERICK. (C) EMMERICK-BUND E. V., DÜLMEN 


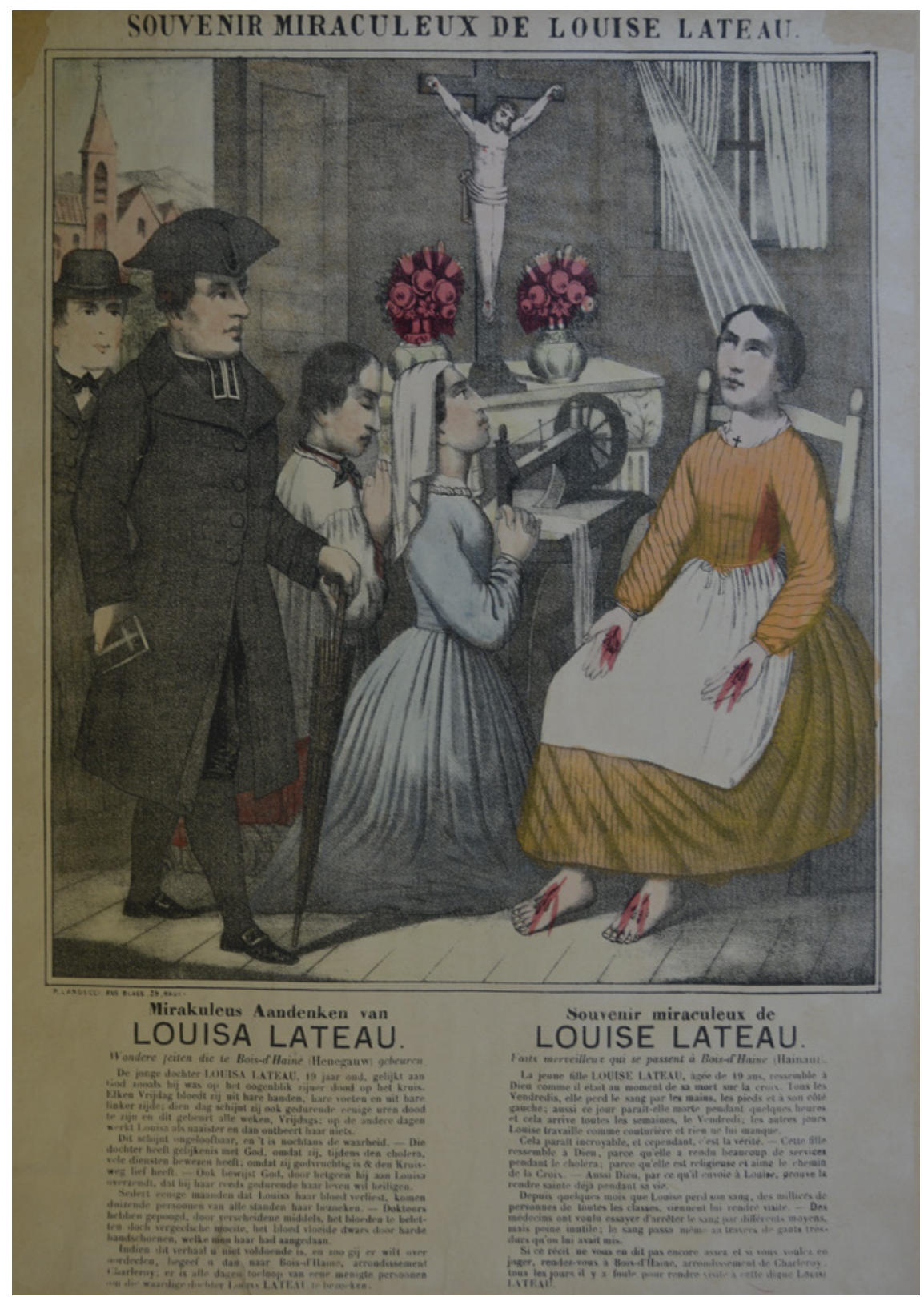

FIGURE 5.3 "Souvenir miraculeux de Louise Lateau" (Landucci) ANTWERP, RUUSBROEC INSTITUTE, COLLECTIE ENGELEN, HEILIGEN EN BEGENADIGDEN, ANNA-LOUIZA LATEAU, H4. (C) RUUSBRoEC INSTitUTE 


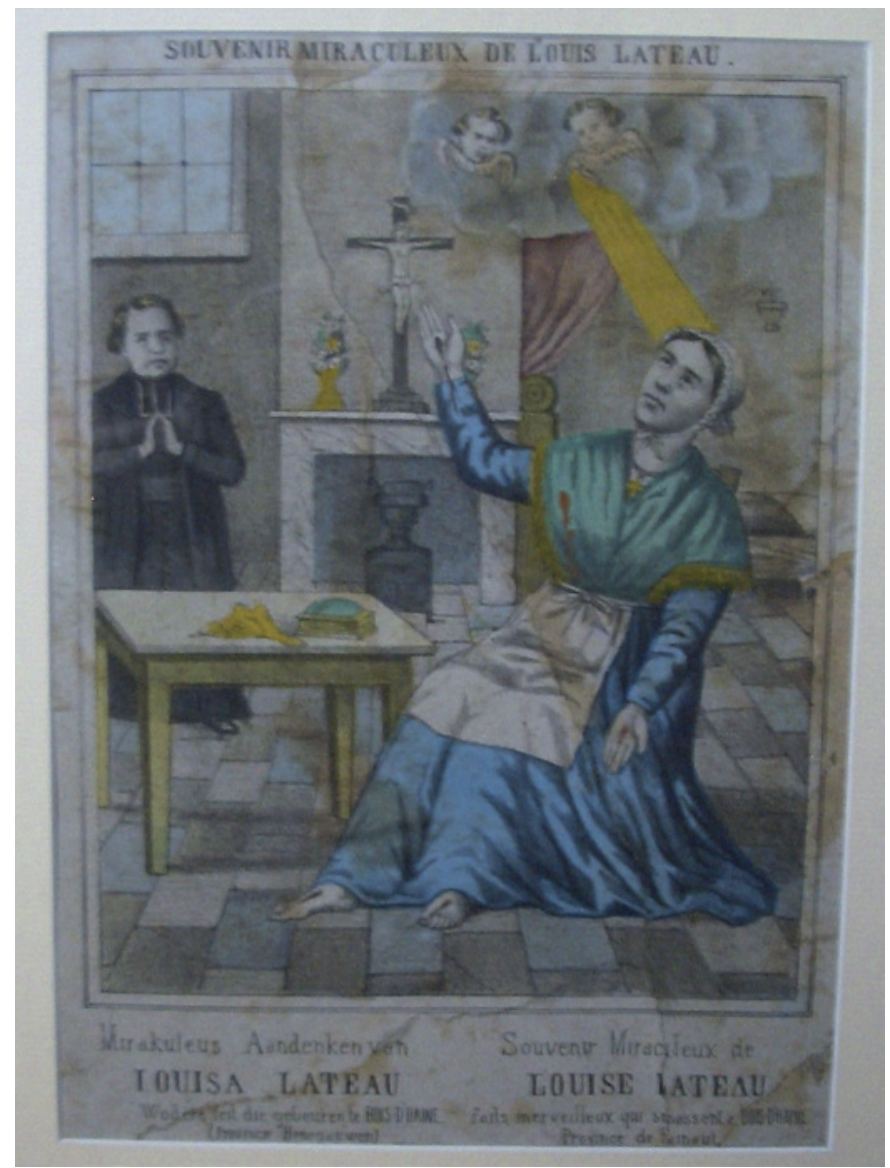

FIGURE 5.4 "Souvenir miraculeux de Louis (sic) Lateau" BOIS-D'HAINE, MAISON LOUISE LATEAU. (C) MAISON LOUISE LATEAU, PHOTOGRAPH AUTHOR 


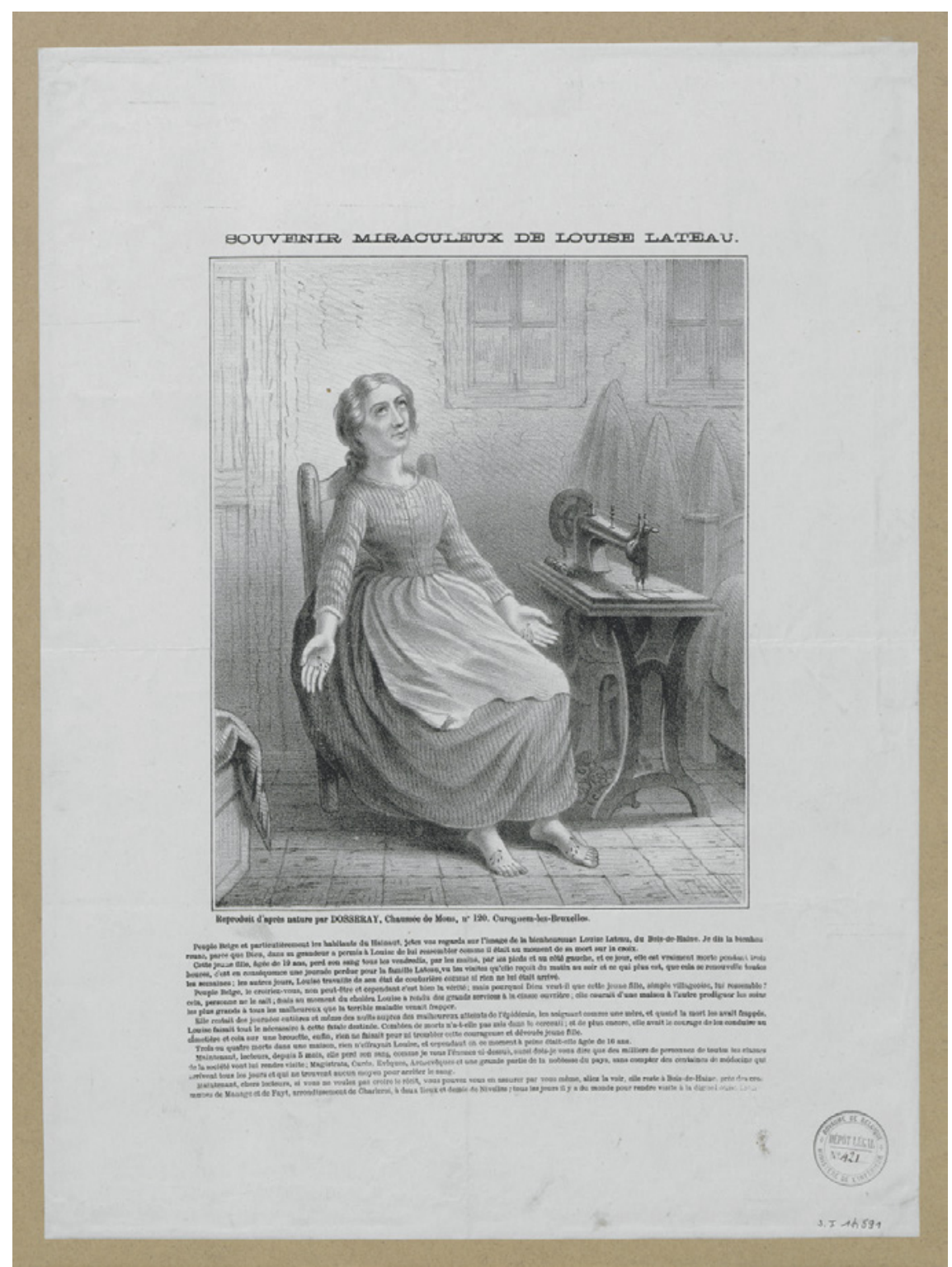

FIGURE 5.5 "Souvenir miraculeux de Louise Lateau" (Dosseray 1869)

BRUXELLES, KONINKLIJKE BIBLIOTHEEK (KBR), PRENTENKABINET, S.I.4591, DOSSERAY 1869. (C) KONINKLIJKE BIBLIOTHEEK 